University of Nebraska - Lincoln

DigitalCommons@University of Nebraska - Lincoln

1977

\title{
Sedimentation Coefficients of the Virions of Soil-Borne Wheat Mosaic Virus
}

Myron K. Brakke

University of Nebraska-Lincoln

Follow this and additional works at: https://digitalcommons.unl.edu/plantpathpapers

Part of the Plant Pathology Commons

Brakke, Myron K., "Sedimentation Coefficients of the Virions of Soil-Borne Wheat Mosaic Virus" (1977). Papers in Plant Pathology. 174.

https://digitalcommons.unl.edu/plantpathpapers/174

This Article is brought to you for free and open access by the Plant Pathology Department at DigitalCommons@University of Nebraska - Lincoln. It has been accepted for inclusion in Papers in Plant Pathology by an authorized administrator of DigitalCommons@University of Nebraska - Lincoln. 


\title{
Sedimentation Coefficients of the Virions of Soil-Borne Wheat Mosaic Virus
}

\begin{abstract}
Myron K. Brakke
Research Chemist, Agricultural Research Service, U.S. Department of Agriculture and also Professor, Department of Plant Pathology, University of Nebraska, Lincoln, NE 68583.

Cooperative Investigations, Agricultural Research Service, U.S. Department of Agriculture and Department of Plant Pathology, Nebraska Agricultural Experiment Station, Lincoln, NE 68583. Published with approval of the Director as Journal Series Paper No. 5236, Nebraska Agricultural Experiment Station.

Mention of a trademark name, proprietary product, or specific equipment does not constitute a guarantee or warranty by the U.S. Department of Agriculture and does not imply approval of it to the exclusion of other products that also may be suitable.

Spinco is a trademark of Beckman Instruments, Inc., Palo Alto, CA 94304; Triton X-100 is a trade name for alkylphenyl-polyethoxy-ethanol marketed by Rohm and Haas, Philadelphia, PA 19105; "Stains-all" is a common name for 1-ethyl-2-\{3-(1-ethylnaphtho [1,2-d]-thiazolin-2-ylidene)-2-methylpropenyl $\}$ naphtho [1,2-d] thiazolium bromide. Accepted for publication 11 May 1977.
\end{abstract}

\begin{abstract}
BRAKKE, M. K. 1977. Sedimentation coefficients of the virions of soil-borne wheat mosaic virus. Phytopathology 67:1433-1438.

The sedimentation coefficient of virion I of soil-borne wheat mosaic virus was estimated to be $219 \mathrm{~S}$, the same, within error, as the sedimentation coefficient of the dimer of virion II, estimated to be $218 \mathrm{~S}$. The monomer of virion II

sedimented at $177 \mathrm{~S}$, and was $138 \mathrm{~nm}$ long. Another strain of the virus had a virion II (designated IIb) that was $92 \mathrm{~nm}$ long and sedimented at $159 \mathrm{~S}$. The two virus strains coexist in some fields.
\end{abstract}

Soil-borne wheat mosaic virus (SBWMV) is a multicomponent virus with rod-shaped virions $(9,20)$. The larger virion (virion I) has RNA of about $2 \times 10^{6}$ daltons molecular weight (9). Other properties of this virion are obscured by the presence of dimers of virion II, whose monomer has an $s_{20 \text {,w }}$ of about $173 \mathrm{~S}$, a length of $150-160 \mathrm{~nm}(1,4,5,8,9,18,19)$ and RNA of about $1 \times 10^{6}$ molecular weight (9).

Tsuchizaki et al. (19) obtained strains of the virus with rods that were 110 and $120 \mathrm{~nm}$ long by mechanical transmission of strains that originally had virions II that were $160 \mathrm{~nm}$ long. These strains still contained a few rods that were $300 \mathrm{~nm}$ long, which were presumably virion I and not dimers of the $110-120 \mathrm{~nm}$ virion II. The $300-\mathrm{nm}$ rods observed by others could have been virion I or dimers of the $150-160 \mathrm{~nm}$ virion II $(1,4,5,9)$.

A virion zone sedimenting at $212 \mathrm{~S}$ has been reported, but this zone contained more RNA II than RNA I and therefore was probably predominantly dimers of virion II (9). I have estimated the sedimentation coefficient of virion I by centrifuging a virion preparation through a sucrose gradient, collecting consecutive samples from the virion zone as the gradient was pumped through a scanner, precipitating the virions in the samples with alcohol, and finally disrupting the precipitated virions with detergent and analyzing their RNA by gel electrophoresis. The gel electrophoretic analysis allows one to estimate the amounts of each type of virion in each sample. The sedimentation coefficient of a virion II from a strain with $92-\mathrm{nm}$ rods is also reported.

Copyright (c) 1977 The American Phytopathological Society, 3340 Pilot Knob Road, St. Paul, MN 55121. All rights reserved.

\section{MATERIALS AND METHODS}

Soil-borne wheat mosaic virus was obtained in April from infected wheat from several fields near Lincoln, Nebraska. One strain, SV17, was maintained on Michigan Amber wheat plants (Triticum aestivum L.) in growth rooms by mechanical inoculation by $\mathrm{C}$. Powell and used by him (16). Virions of other strains were purified from infected wheat collected from the field in April and stored at $-20 \mathrm{C}$ until purification. Virions were purified by the following modifications of our earlier method (17). One percent Triton X-100 was used instead of $0.1 \%$ Igepon $\mathrm{T}-73$, and high-speed pellets were suspended in $\mathrm{pH} 7.5,0.05 \mathrm{M}$ sodium orthoborate. In a final purification step, the virions in $0.05 \mathrm{M}$ sodium orthoborate, $\mathrm{pH}$ 7.5, were layered over a gradient prepared from $4 \mathrm{ml}$ each of $50,100,150$, and $200 \mathrm{mg}$ of

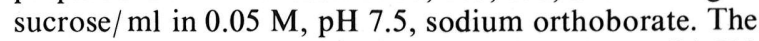
gradients were centrifuged for $3 \mathrm{hr}$ at $25,000 \mathrm{rpm}(81,500$ average $g$ ) at $5 \mathrm{C}$ in the Beckman SW27 rotor. The pellet was suspended in $\mathrm{pH} 7.5,0.05 \mathrm{M}$ sodium orthoborate and stored at $-20 \mathrm{C}$ after addition of $5 \%$ ethylene glycol.

The sedimentation coefficients of individual virions were estimated essentially as described for barley stripe mosaic virus (2). The sucrose for the gradient columns for SBWMV was dissolved in $0.1 \%$ Igepon T-73 to inhibit virion aggregation (9). Linear-log gradients were centrifuged in either the Beckman SW41 or SW27 rotors at $5 \mathrm{C}(3)$. Analysis of the gradients, collection of samples, gel electrophoretic analysis of the RNA, and interpretation of the results was as described earlier (2). Peacock and Dingman's (15) $0.09 \mathrm{M}$ tris borate buffer was used for some of the RNA analyses. 
Molecular weights of RNAs were estimated by gel electrophoresis of formaldehyde-treated RNA as described by Lane (13) except that gels contained $2.2 \%$

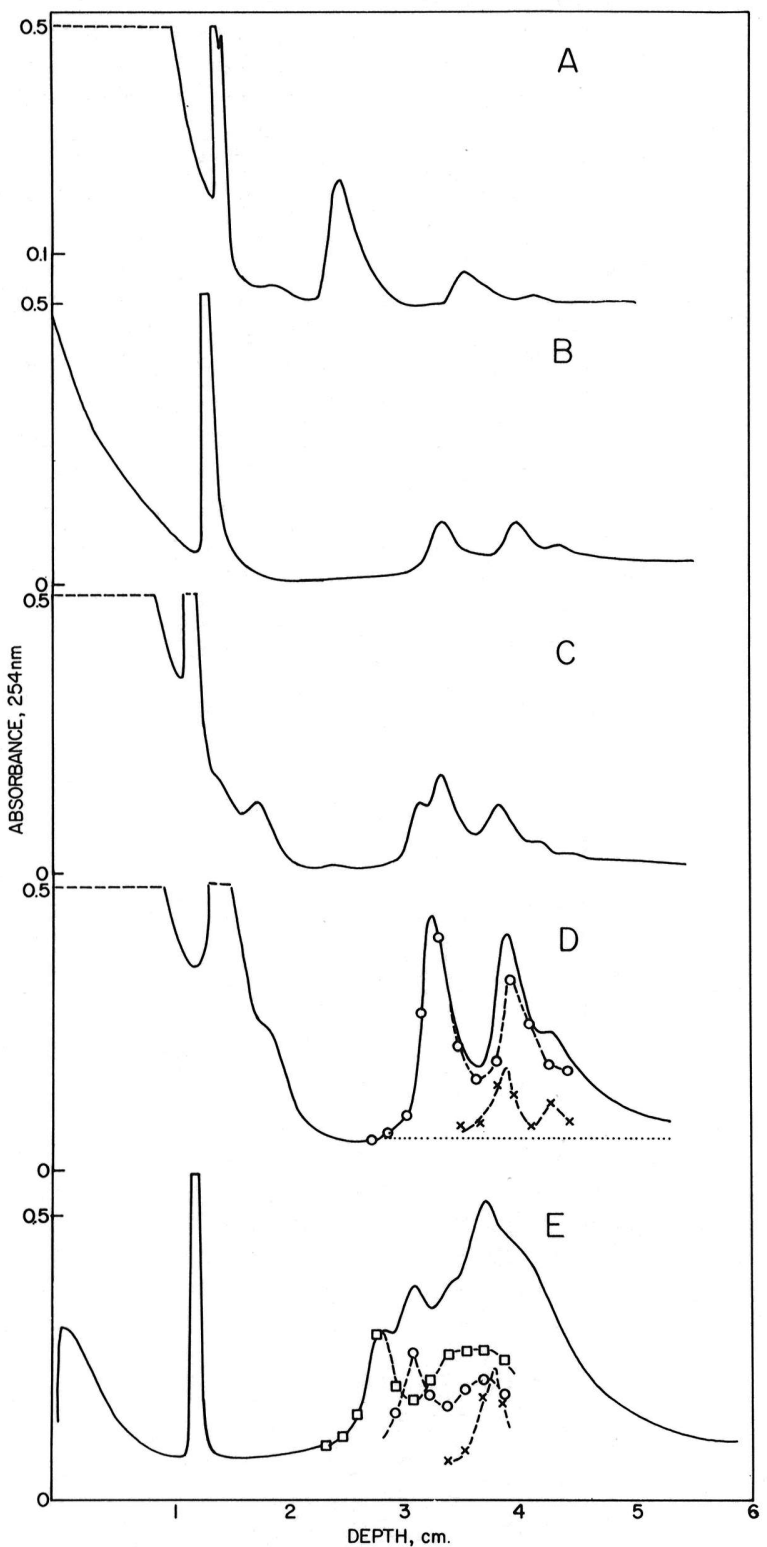

Fig. 1. Photometric scanning patterns of virions centrifuged through a linear log sucrose gradient column. Pattern $\mathrm{A}$ is of southern bean mosaic (SBMV) $(50 \mu \mathrm{g})$ and tobacco mosaic (TMV) virions (clarified extract 1:50); pattern $B$ is of a culture of soil-borne wheat mosaic virus (SBWMV, $1 \mathrm{mg}$ ); pattern $\mathrm{C}$ is a mixture of TMV and SBWMV; pattern D is of a larger amount $(8 \mathrm{mg}$ ) of SBWMV; and pattern E is $3 \mathrm{mg}$ of strain SV17 of SBWMV. The dashed lines show the results of analysis of samples for individual components of SBWMV-RNA. The circles ( 0 ) show the amount of RNA II, the squares of IIb, and the crosses $(x)$ of RNA I. Linear log sucrose gradient columns dissolved in $0.1 \%$ Igepon T-73 were centrifuged for $2 \mathrm{hr}$ at 25,000 $\mathrm{rpm}(81,500$ avg $g)$ in the Beckman SW27 rotor at $5 \mathrm{C}$. Gradients were scanned at $254 \mathrm{~nm}$ at $3 \mathrm{ml} / \mathrm{min}$ and samples collected at 15 sec intervals. The peak at $1.0-1.5 \mathrm{~cm}$ is the detergent. acrylamide and $0.5 \%$ agarose. After electrophoresis gels were soaked $1.0 \mathrm{hr}$ in water, stained overnight in "stainsall" (7), and destained in water in a dim light.

Tobacco mosaic virus RNA at $2.05 \times 10^{6}$, and E. coli RNA at 0.56 and $1.1 \times 10^{6}$ were molecular weight standards in gel electrophoresis of $\operatorname{RNA}(6,12)$. Virions of TMV and southern bean mosaic virus with $s_{20, w}$ values of $190 \mathrm{~S}$ and 115S, respectively, were sedimentation standards in sucrose density-gradient centrifugation of SBWMV (3). Purified southern bean mosaic virus was used, but the TMV was a fresh, clarified extract of infected leaves at dilutions of 1:20 to $1: 50$ ( $\mathrm{g}$ of leaves $/ \mathrm{ml}$ ).

Virions were prepared by two methods for length measurements by electron microscopy. In the first, a freshly cut leaf was immersed for a few seconds in a drop of water on a specimen grid. The drop was dried for 20-30 min, a drop of negative stain was applied, and the sample was examined in a RCA $3 \mathrm{G}$ electron microscope at about $\times 15,000$. In the second procedure, a $0.5-$ to $1.0-\mathrm{cm}$ portion of a leaf was chopped with a razor blade in a large drop of water or salt solution on a Parafilm membrane to give a slightly yellowish-green drop. A specimen grid with carbon-backed parlodion film was floated film side down on the drop for $10 \mathrm{~min}$. Excess liquid was removed, and the grid was immediately stained and examined as before. A solution of $1.5 \%$ sodium phosphotungstate and $0.5 \%$ ammonium vanadatomolybdate was usually used for the negative stain. Purified virus for width measurements was prepared according to Horne and Pasquali-Ronchetti (11). Widths were measured from edge to edge across three or more rods lying side-by-side. The magnification of the microscope was calibrated with a replica of a diffraction grating.

\section{RESULTS}

Virions from several sources of SBWMV were examined by sedimentation and the two showing least aggregation were selected for further investigation. The sedimentation of a typical two component strain of SBWMV is shown in Fig. 1(B, D). The RNA analysis by gel electrophoresis of the samples collected from the gradient column of Fig. 1-D are shown in Fig. 2. It is apparent that the two peaks on the absorbance scanning pattern of SBWMV are the monomer and dimer of virion II.

Figure 1-C, shows a mixture of SBWMV and TMV cosedimented in the same column. The sedimentation coefficients of the monomer and dimer of virion II were calculated from depths measured from a gradient column such as Fig. 1-C, with TMV serving as an internal standard. The slope of the line of the log-log plot (3) was taken from the depths of southern bean mosaic virus and TMV measured in a companion gradient (Fig. 1-A). When values for the monomer and dimer of virion II had been accumulated for several gradients such as shown in Fig. 1-C, an average value for the sedimentation coefficient of these two particles was calculated (Table 1). The monomer and dimer peaks of virion II were then used as internal standards for the calculation of the sedimentation coefficient of virion I from patterns such as that of Fig. 1-D, with the position of virion I determined by RNA analysis (Fig. 2). Within the error of the method, virion I sedimented at the same rate $(219 \mathrm{~S})$ as the dimer of 
virion II (218S) (Table 1).

Strain SV17, which had been maintained by mechanical inoculation for $3 \mathrm{yr}$, had a third RNA, smaller than RNA II, which was found in a virion sedimenting slower than virion II. This RNA is designated RNA IIb and the virion, virion IIb. The sedimentation pattern of the virions of strain SV17 is shown in Fig. 1-E. Because virion IIb could be detected on absorbance patterns, it sedimentation coefficient was estimated from depths of virions measured on absorbance patterns with the monomer and dimer of virion II serving as internal standards (Table 1).

Three RNAs have been found not only in strain SV17, but also in virions purified from infected plants from certain fields. The RNA pattern of virions purified from wheat from one such field in 1972 is shown in Fig. 3-A. RNA from virions purified from wheat collected from the same field in 1974 did not have a discrete third RNA peak (Fig. 3-B). The results of gel electrophoretic analysis of the formalinized SBWMV-RNA from this field, alone and in combination with TMV RNA and E. coli RNA as internal markers, are shown in Fig. 3-B and -C. Patterns of formaldehyde-treated RNA are shown for the comparison with TMV because untreated TMV RNA often showed multiple zones. Formaldehyde treatment did not change the number of components of SBWMV RNA nor their relative concentrations. Inspection of the stained gels showed a doublet zone of TMV-RNA and SBWMV-RNA I. The doublet was barely resolved in the scanning pattern (Fig. 3-C). From the relative amounts of the two components, the slower migrating component of the doublet was identified as SBWMV-RNA I. The apparent molecular weights of SBWMV-RNA's I and II calculated from gel electrophoretic mobility after formaldehyde treatment are given in Table 1 . No difference could be detected in the molecular weights of SBWMV-RNA's I and II from different fields.

Rod-length measurements on strain SV17 confirmed the presence of virion IIb and, in fact, showed that some plants contained virion II and some contained virion IIb (Fig. 4). Measurements made on leaf dips prepared by procedure I (see Materials and Methods) gave a wide distribution of lengths. The results of these measurements did not correlate with virion lengths expected from RNA

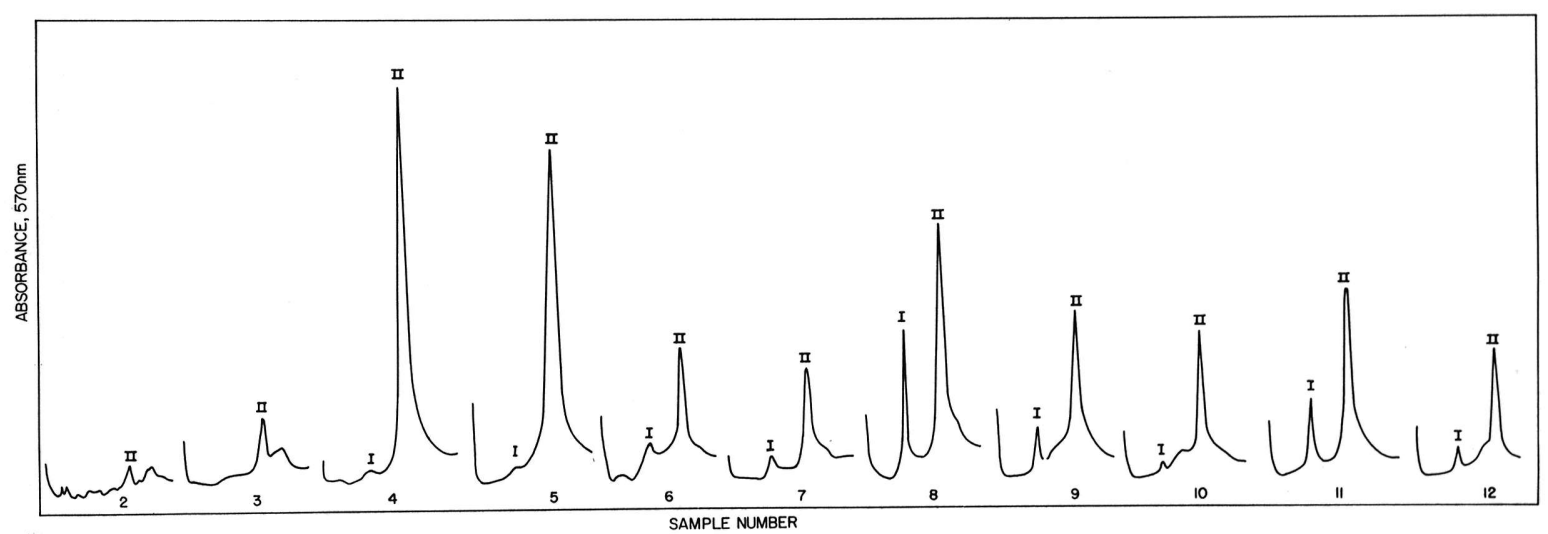

Fig. 2. Gel electrophoretic analysis of RNA from consecutive samples collected from the virion zone of the sucrose gradient column D of Fig. 1. Results of analysis of all samples except the first are shown. No RNA was detected in the first sample. The gel was $2.5 \%$ acrylamide with $0.5 \%$ agarose and the buffer was $0.09 \mathrm{M}$ tris, $0.09 \mathrm{M}$ borate, $2.7 \mathrm{mM}$ EDTA. Gels were stained in Stains-all and scanned at $570 \mathrm{~nm}$.

TABLE 1. Properties of components of soil-borne wheat mosaic and tobacco mosaic viruses

\begin{tabular}{|c|c|c|c|c|c|}
\hline \multirow[t]{2}{*}{ Virions } & \multicolumn{4}{|c|}{ Component $^{\mathrm{a}}$} & \multirow[b]{2}{*}{ TMV } \\
\hline & $\mathrm{I}$ & II & $\mathrm{IIb}$ & II-dimer & \\
\hline $\begin{array}{l}\text { Estimated } S_{w, 20} \\
\text { No of determinations }\end{array}$ & $219 \pm \frac{1.6 S^{b}}{6}$ & $177 \pm \frac{1.0 S}{5}$ & $159 \pm \frac{1.1 \mathrm{~S}}{4}$ & $218 \pm \frac{1.0 S}{5}$ & $190 \mathrm{~S}^{\mathrm{h}}$ \\
\hline $\begin{array}{l}\text { No. of determinations } \\
\text { Rod length }\end{array}$ & $281 \mathrm{~nm}^{\mathrm{f}}$ & $138 \mathrm{~nm}$ & $92 \mathrm{~nm}$ & ND & $281 \mathrm{~nm}$ \\
\hline No. $\operatorname{rods}^{\mathrm{c}}$ & 134 & 714 & 1,546 & ND & 468 \\
\hline No. of plants ${ }^{\mathrm{d}}$ & 15 & 9 & 15 & ND & 3 \\
\hline Width & $20 \mathrm{~nm}$ & $20 \mathrm{~nm}$ & $20 \mathrm{~nm}$ & $20 \mathrm{~nm}$ & $16.5 \mathrm{~nm}^{6^{\mathrm{h}}}$ \\
\hline RNA, mol wt, gels ${ }^{\mathrm{e}}$ & $2.10 \times 10^{6}$ & $1.4 \times 10^{6}$ & $\mathrm{ND}^{\mathrm{g}}$ & ND & $2.05 \times 10^{6}$ \\
\hline
\end{tabular}

${ }^{\mathrm{a}}$ The largest component is termed number I. Most strains have I and II, some I and IIb, and some all three.

bStandard error of the mean. This indicates the reproducibility of the measurements, not the absolute accuracy. Based on $190 \mathrm{~S}$ for TMV and $115 \mathrm{~S}$ for southern bean mosaic virus.

${ }^{\mathrm{c}}$ Number of rods measured in each particular size class.

${ }^{\mathrm{d}} \mathrm{Number}$ of plants from which virions were obtained for length measurements.

${ }^{\mathrm{B}}$ Based on electrophoretic mobility in gels after formaldehyde treatment.

'The 281 -nm rods were in the 15 plants containing virion IIb.

${ }^{8}$ The abbreviation ND = not determined.

${ }^{\mathrm{h}}$ Literature values. Caspar, 1963. Adv. Protein Chem. 18:37-121. 
analysis. When the leaf-dip procedure was modified to procedure II, measurements showed a much narrower distribution of rod lengths (Fig. 4) and the results correlated with the RNA analysis. It should be noted that plants with virions IIb (92 nm long) contained as many rods that were $281 \mathrm{~nm}$ long as did plants with virion II of

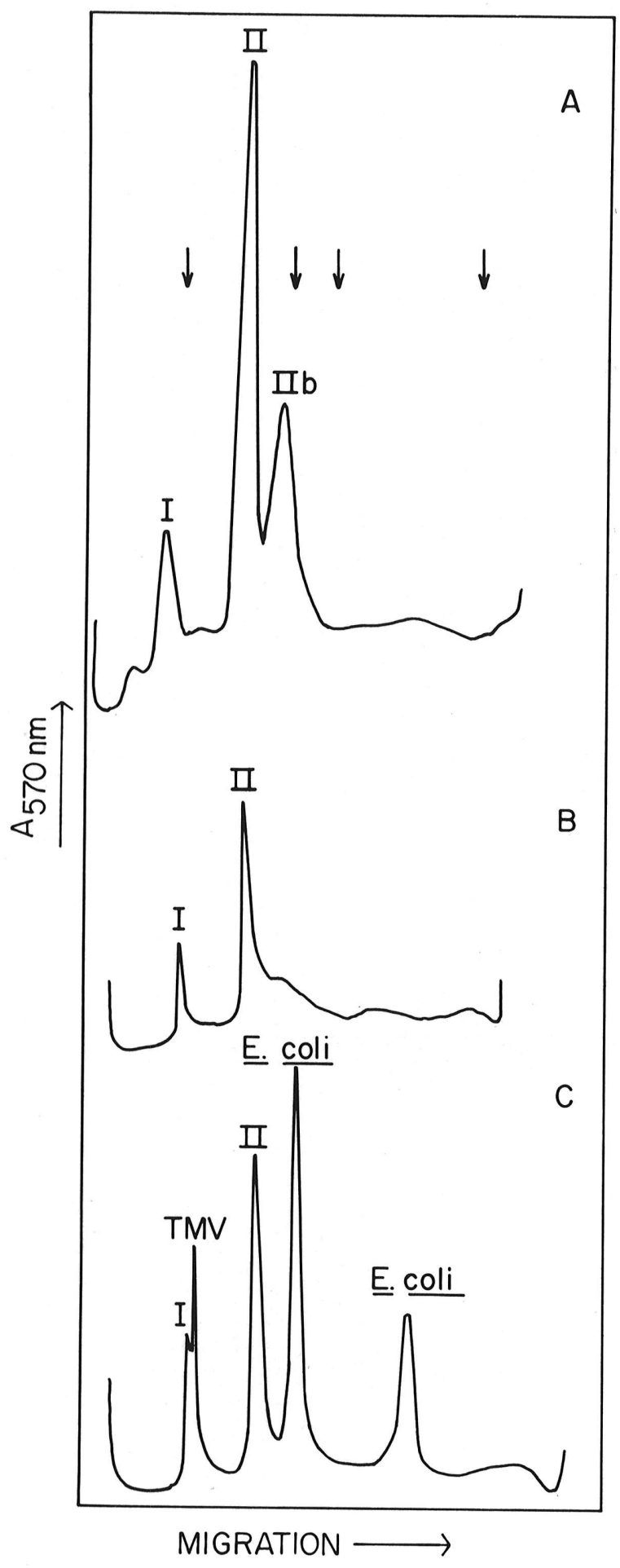

$138 \mathrm{~nm}$. These $281-\mathrm{nm}$ rods could not have been dimers of the $92-\mathrm{nm}$ rods and are presumed to have been rods of virion I. In procedure II, the leaves were usually chopped in $0.5 \mathrm{M}$ borate, $\mathrm{pH} 9.0$, but $0.5 \mathrm{M}$ borate $\mathrm{pH} 8.0$, distilled

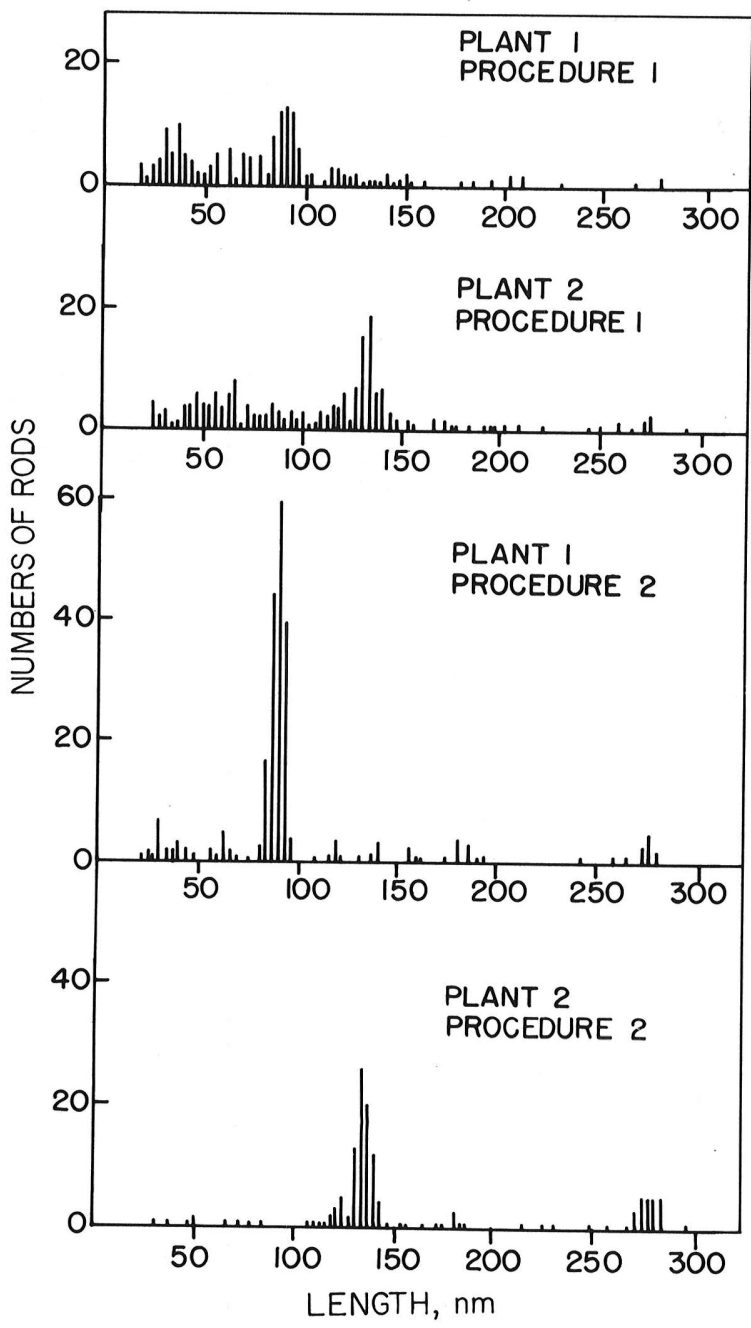

Fig. 4. Histogram of length distribution of rods from two plants infected with SBWMV strain SV17 that had been maintained by mechanical inoculation. Grids were prepared by two procedures (see text for details) from each plant. One plant had 92- and 281-nm rods, the other, 138- and 281-nm rods.

Fig. 3. Gel electrophoresis of RNA from purified SBWMV. Pattern A is of RNA of virus from infected wheat of 1972, not treated with formaldehyde and run in $2.4 \%$ acrylamide, $0.5 \%$ agarose, with $0.03 \mathrm{M} \mathrm{NaH}_{2} \mathrm{PO}_{4}, 0.03 \mathrm{M}$ tris, $1.5 \mathrm{mM}$ EDTA buffer. Arrows indicate (from the left) the position of TMVRNA, brome mosaic virus (BMV)-RNA II, BMV-RNA III, and BMV-RNA IV in a companion gel. Pattern $B$ is of formaldehyde-treated SBWMV-RNA from virus purified from the same field in 1974. The gel was $2.2 \%$ acrylamide and $0.5 \%$ agarose and the buffer was $0.02 \mathrm{M} \mathrm{Na}_{2} \mathrm{HPO}_{4}, 0.01 \mathrm{M} \mathrm{NaH}, \mathrm{PO}_{4}$ and $1 \mathrm{mM}$ EDTA. Pattern $C$ is the same as pattern $B$, except that TMV-RNA and Escherichia coli rRNA were added as internal standards. 
water, and negative stain itself all gave nearly equal results. The high dilution of the virions in procedure I, the length of time involved, and the drying of the grids all appeared to be detrimental.

The average lengths of virions I, II, and IIb of SBWMV are given in Table 1; TMV, measured by chopping leaves as per procedure II, was $281 \mathrm{~nm}$ long.

Because virion I of SBWMV is the same length as TMV, the more rapid sedimentation of SBWMV can be explained only if it has a larger diameter than TMV. The diameters of the virions of these two viruses were measured by electron microscopy and found to be $20 \mathrm{~nm}$ for SBWMV (Table 1) and 16.5 for TMV, which agree well with previously published values $(4,6,18)$.

Strain SV17 was lost in a fire in August, 1975 that destroyed the growth rooms in which this strain was maintained. Attempts to recover a strain of the virus with virion IIb have been unsuccessful. Therefore, it has been impossible to measure certain properties of this virion, such as the apparent molecular weight of RNA IIb.

\section{DISCUSSION}

The fact that virion I of SBWMV sediments at almost exactly the same rate as the dimer of virion II suggests that virion I should be twice as long as virion II. These results and the RNA data support the conclusion that some of the rods of approximately $300 \mathrm{~nm}$ seen in the electron microscope are those of virion $\mathrm{I}$.

The molecular weights of SBWMV-RNA's I and II determined by gel electrophoresis after formaldehyde treatment are larger than those determined by centrifugation of formaldehyde-treated RNA (9). The difference for RNA I (2.10 vs. $1.84 \times 10^{6}$ daltons) may not be outside the combined errors of the two methods, but the discrepancy for RNA II $\left(1.4 \times 10^{6}\right.$ daltons by gel electrophoresis vs. $0.95 \times 10^{6}$ daltons by centrifugation) is larger than the expected error. It is probable that formaldehyde did not destroy all the secondary structure, particularly that of RNA II, and that the correct value of its molecular weight is somewhere between 0.95 and $1.4 \times$ $10^{6}$ daltons. The relative sedimentation rates of the virions suggests that RNA II should have half the molecular weight of RNA I.

Present results confirm the report of Tsuchizaki et al. (19) of strains of SBWMV with short rods of different lengths. Such strains apparently coexist in some fields in Nebraska, with short rods (virion IIb) being a minor and variable component. The results of Tsuchizaki et al. (19) and my results suggest that virion IIb may have a selective advantage over virion II in virus maintained by mechanical transfer.

Present measurements give lengths of SBWMV virions shorter than those reported previously for the Nebraska virus (1) and the sedimentation coefficients are slightly higher than those reported earlier (9). The differences probably result from differences in procedures, standards, and in sedimentation coefficients assigned to the standards. Such variation is common. Even for TMV, careful electron microscopic measurements do not agree (e.g., see 10,14). The 138- and 281-nm rods of SBWMV of the present report are probably the same as the 160- and $300-\mathrm{nm}$ rods reported earlier (1), though they were obtained from measurements on virus from a different field and prepared by a different procedure.

The SBWMV resembles TMV in many respects and is slightly related serologically (16); it differs from TMV in having a larger diameter which results in faster sedimentation of rods of equal length. The weight that should be given these various differences and similarities when considering the taxonomy of these viruses is unclear.

\section{LITERATURE CITED}

I. BRAKKE, M. K., A. P. ESTES, and M. L. SCHUSTER. 1965. Transmission of soil-borne wheat mosaic virus. Phytopathology 55:79-86.

2. BRAKKE, M. K., and M. K. PALOMAR. 1976. Separation of components of barley stripe mosaic virions by densitygradient centrifugation. Virology 71:255-261.

3. BRAKKE, M. K., and N. VAN PELT. 1970. Linear-log sucrose gradients for estimating sedimentation coefficients of plant viruses and nucleic acids. Anal. Biochem. 38:56-64.

4. BRANDES, J., M. R. PHILliPPE, and H. H. THORNBERRY. 1964. Electron microscopy of particles associated with soil-borne wheat mosaic. Phytopathol. Z. 50:181-190

5. CANOVA, A. 1964. Ricerche sulle malattie da virus delle Graminacee. I. Mosaico del Frumento transmissible attravirso il terreno. Phytopathol. Mediterr. 3:86-94.

6. CASPAR, D. L. D. 1963. Assembly and stability of the tobacco mosaic virus particle. Advan. Protein Chem. 18:37-121.

7. DAHLBERG, A. E., C. W. DINGMAN, and A. C. PEACOCK. 1969. Electrophoretic characterization of bacterial polyribosomes in agarose-acrylamide composite gels. J. Mol. Biol. 41:139-147.

8. GOLD, A. H., H. A. SCOTT, and H. H. MC KINNEY. 1957. Electron microscopy of several viruses occurring in wheat and other monocots. Plant Dis. Rep. 41:250-253.

9. GUMPF, D. J. 1971. Purification and properties of soilborne wheat mosaic virus. Virology 43:588-596.

10. HALL, C. E. 1958. Lengths of tobacco mosaic virus from electron microscopy. J. Am. Chem. Soc. 80:2556-2557.

11. HORNE, R. W., and I. PASQUALI-RONCHETTI. 1974. A negative staining - carbon film technique for studying viruses in the electron microscope. I. Preparative procedures for examining icosahedral and filamentous viruses. J. Ultrastruct. Res. 47:361-383.

12. KURLAND, C. G. 1960. Molecular characterization of ribonucleic acid of Escherichia coli ribosomes. I. Isolation and molecular weights. J. Mol. Biol. 2:83-91.

13. LANE, L. C. 1974. The components of barley stripe mosaic and related viruses. Virology 58:323-333.

14. MARKHAM, R., J. H. HITCHBORN, G. J. HILLS, and S. FREY. 1964. The anatomy of tobacco mosaic virus. Virology 22:342-359.

15. PEACOCK, A. C., and C. W. DINGMAN. 1967. Resolution of multiple ribonucleic acid species by polyacrylamide gel electrophoresis. Biochemistry 6:1818-1827.

16. POWELL, C. A. 1976. The relationship between soil-borne wheat mosaic virus and tobacco mosaic virus. Virology 71:453-462.

17. RAO, A. S., and M. K. BRAKKE. 1969. Relation of soilborne wheat mosaic virus and its fungal vector, Polymyxa graminis. Phytopathology 59:581-587.

18. SAITO, Y., K. TAKANASHI, and Y. IWATA. 1961. Purification and morphology of Japanese soil-borne wheat mosaic viruses. Ann. Phytopathol. Soc. Japn. 26:16-18.

19. TSUCHIZAKI, T., H. HIBINO, and Y. SAITO. 1973. 
Comparisons of soil-borne wheat mosaic virus isolates from Japan and the United States. Phytopathology 63:634-639.
20. TSUCHIZAKI, T., H. HIBINO, and Y. SAITO. 1975. The biological functions of short and long particles of soilborne wheat mosaic virus. Phytopathology 65:523-5.32. 